\title{
The Sufi Phenomenology of Love Based on the Thoughts of Rabia Al-Adawiyya and Edith Stein
}

\author{
KONUL BUNYADZADE 1
}

\begin{abstract}
This article contributes to research on the consideration of the phenomenon of Love through a comparison of the thoughts of Sufi thinker Rabia al-Adawiyya (713-801) and phenomenological philosopher Edith Stein (1891-1942). The author studies the poems of Rabia and the final work of Edith Stein, where she discussed her views on divine love, "Science of Cross". The main aim of the article is a search for the crossing point between Sufism and Phenomenology. The author considers three stages of phenomenological reduction: faith, hope and love. First, the heart is considered as a noematic core and the result of epoché. The second part of the article is an investigation into the second stage of phenomenological reduction, hope, which is studied as a transition between rational and irrational thoughts. In the third part of the article, divine love is investigated as a process of perfection in Sufism and of phenomenological reduction in phenomenology. In conclusion, the essence of love is presented on the basis of Sufi phenomenology, where the principles of Sufism and phenomenology are in contact. In other words, the consideration oflove is a method of representing Sufi phenomenology as a new philosophical doctrine.
\end{abstract}

Keywords: Edith Stein, phenomenology of love, phenomenological reduction, Sufi phenomenology, Rabia al-Adawiyya

This article investigates the phenomenology of love through a comparison of the work of Rabia al-Adawiyya, who first introduced 'divine love' in Sufism, and Edith Stein, a phenomenologist whose way of life was determined by divine love. Rabia al-Adawiyya and Edith Stein followed different religions, Islam and Christianity, and they lived in different times. This comparative analysis of their views includes some important details about love. Rabia and Stein knew their religion and were true believers. On the one hand, their thought is based on religion; on the other hand, Rabia was a Sufi thinker and Stein a phenomenologist. Both of them presented love as a process of improvement and a way of achieving perfection. Therefore, this investigation will be a study of love based on a comparison between Islam and Christianity, on the one hand, and Sufism and Phenomenology on the other. This comparison will ultimately consider the phenomenology of love.

\section{The Heart as a Noematic Core}

The heart - 'fu 'ad' - is a term that is often found in love poems and thoughts about love. The Noble Quran uses the word only once: "The heart did not lie [about] what it saw" (al-Quran 53:11). There is an important detail to note: the heart is the means by which man can come the closest to his Creator: "And was at a distance of two bow lengths or nearer" (al-Quran 53:9). Only here can a man receive divine knowledge. "And he revealed to His Servant what he revealed" (al-Quran

\footnotetext{
${ }^{1}$ Konul Bunyadzade, Ph.D., professor and the head of the Department of Islamic Philosophy, Institute of Philosophy, Azerbaijan National Academy of Sciences, H.Cavid Avenue, 115, AZ1073 BAKU, Republic of Azerbaijan, email: bkonul885@hotmail.com.
} 
53:10). In other words, the heart is the only way to be in direct contact with God. Rabia calls the Lord 'the companion of heart' or 'the friend of heart':

I have made You the companion of my heart.

But my body is available to those who desire its company,

And my body is friendly toward its guest,

But the Beloved of my heart is the guest of my soul (al-Adawiyya 2016: 95).

Rabia notes an important moment: eternity is not found in relative feelings, but in the heart. A feature of the heart is the condition known as hal (condition) in Sufism. The desires of the body are external and cannot reach deep into the heart. However, they are not rejected or isolated as features of the body. Love is the highest condition of the heart, where man can receive divine knowledge and eternal wisdom. Rabia considers love as the language for the highest moments of the heart, or as a light in conversations with God. In other words, love is not a conversation: it is a common language between man and God:

In love, nothing exists between heart and heart.

Speech is born out of longing,

True description from the real taste.

The one who tastes, knows;

The one who explains, lies.

How can you describe the true form of Something

In whose presence you are blotted out?

And in whose being you still exist?

And who lives as a sign for your journey? (Sufi Poems 2015: 22).

Thus, as love is direct contact with God, it gives us a new perspective. Love is an opportunity to see or hear what the eyes and ears cannot. It is an opportunity to define the essence of things:

When God said, "My hands are yours,"

I saw that I could heal any creature in this world;

I saw that the divine beauty in each heart

Is the root of all time

And space (Love Poems from God 2002: 1).

Edith Stein, a representative of 'rigorous science', also writes about the spiritual experience of the heart. The soul or heart is the 'divine core' of the man. It is a way to be in touch with God. This is the beginning of the process of perfection:

Under the influence of the spiritual light, the objects seen are impressed so deeply on the soul that every time she adverts to them by the grace of God, she beholds them as she did the first time. They engender peace and clarity, heavenly joy, pure love, humility and an elevation and inclination toward God in the soul (Stein 2002: 57).

The heart is the beginning, the first and the last point of the path to God. The heart is the way to God and the place of Lord: 
"God has created human souls for himself. He desires to unite them to himself and to give them the immeasurable fullness and incomprehensible bliss of his own divine life, already in this life" (Stein 2002: 46).

Accordingly, the heart or soul performs the function of the noematic core in phenomenology. Thus, if the man is noema, his core is his heart. The phenomenological reduction or epoche is a method of the consciousness. As the consciousness "set asides" all knowledge, experiences, senses and attains the pure condition, so man is purified of his attachments to the material world and achieves a pure heart by means of three main conditions of the spirit: faith, hope and love. Edith Stein does not accept any mediator between man and God. She thinks that: "The divine light, already dwells in the soul by nature". (Stein 2002: 46)

There is an important point in her words: there is a light in the heart of man. If anybody cannot see this light he sees dark and emptiness. Therefore, humankind is not burdened with Original Sin, but has a spirit filled with divine light. This is intentionality: the mind of man focuses on the divine light and understands the properties of things in this light. This is not a psychological act, as in Franz Brentano, but the working of an active consciousness, as in Husserl. Humankind seeks its essence and the essence of things. Man possesses divine love by nature, so he/she seeks and looks for it. Consequently, the man standing at the starting point is not guilty, but a bearer of divine love.

The beginning of the journey is faith. It is the most difficult stage, because it requires faith to set out on a new path after the abandoning a previous life. This is faith in the power to begin an unknown life. Stein writes:

"The point of departure is the desire for the things of this world, which the soul must renounce. However, this renunciation transplants her into darkness and as though into nothingness... In fact, we are set upon a surer way, albeit a dark way, one engulfed by night, the way of faith. It is a way, for it leads to the goal of union" (Stein 2002: 30-31).

Humankind believes in the existence of light in the dark and looks for it. At the beginning of the journey, man cannot see or know anything; he only believes. That is why Stein calls it Dark Night. Faith purifies man from reliance on merely mental conclusions. It should be noted that these conclusions lead to the same stage or level, where man is able to rise beyond the mind - to "a distance of two bow lengths or nearer" by the heart. Abandonment does not mean ignorance: it means abandoning the rational frame, its opportunities and its truth. At this stage, the man who is in darkness can see another light: divine light. Consequently, the second stage, hope, begins.

\section{Hope as Transition from the Rational Stage of the Thought to the Irrational}

In Sufism the haal (condition) of hope comes after love - the lover is able to abandon everything and accepts a new power only if he has hopes in the loved one. As Rabia writes:

If I adore You out of fear of Hell, burn me in Hell!

If I adore you out of desire for Paradise,

Lock me out of Paradise.

But if I adore you for Yourself alone,

Do not deny to me Your eternal beauty (Love Poems from God 2002: 20).

For her, every object lying between her and God is an obstacle. Quran says: "We are closer to him than [his] jugular vein" (al-Quran 50: 16). 
There is no place for any mediator. By mediator is meant the prophet of religion and thoughts about Heaven and Hell. In other words, every materialized essence is an obstacle to the spiritual, divine stage. Rabia notes: "Each love is now alone with his beloved". The beloved is a limit of perfection in the love. This is why Rabia desires only "eternal love" from the Creator, as only this leads to the highest moment of perfection. The more the love, the more hope there is in the journey to God.

This love does not leave any place for hatred of the Demon, as all senses are irrelevant and powerless. The heart that loves God cannot see anybody else. Unlike the Demon, this love does not include hatred of other beings. This is an important point. Love of humankind does not fixate on itself and does not cease half ways along the journey. Humankind recognizes the wisdom of love, and this cognition brings it as close as is possible to God. Rabia's poems about the love of God recite the wisdom of this haal, not feelings. Therefore, more hope means more divine knowledge, and Edith Stein believes that hope helps man to sustain himself after the abandonment of all achieved material goals in a previous life. In particular, the negation of remembrance and memory liberates man completely. It reminds us of Francis Bacon's classification of the intellectual fallacies, which he called idols: idols of the Tribe, idols of the Cave, idols of the Marketplace and idols of the Theater. Unlike Bacon, for Stein, the next world after the abandonment is something beyond the material world. The memory has an important function during a union with God: it retains knowledge. Love cleans the memory of all material knowledge, to create a place for new knowledge. Stein (2002: 46) writes: "Hope puts the memory into emptiness since it occupies it with something that one does not possess".

The memory that is freed from all material relations and knowledge becomes ready and empty to receive divine knowledge and impressions. No words or language are able to express this knowledge. In tasawwuf, this moment or haal is compared with lightning or iridescent stars. Consequently, the memory takes the whole burden upon itself and becomes the index of the heart. We should restate an important fact here - as faith gives new opportunities for the mind, liberates it from material obstacles and introduces divine light to it, so hope conducts this process in the memory. The goal is to prepare man for union with God.

\section{Love as Phenomenological Reduction}

Human beings can seek Love if they can purify themselves from material needs and rational conclusions. This is the phenomenological reduction of the heart, the process of purification. We have arrived at an important moment: the journey beginning with love leads to love again. Rabia presents the stages of the way to love, both together and apart. There are many thoughts about the levels and stages of love. The truth is that the highest level of love is only for those who have been exalted by their thoughts and morality and who are chosen by God. Rabia is chosen by God. Her thoughts, haals, belong to a person who can reach the highest peak of love. Moreover, the end of this journey is the moment of being in touch with God, the opportunity to see the Creator in all creatures. This is the haal of Certainty. We should note an important detail: in this highest haal, "at a distance of two bow lengths or nearer" man is still a human being, not a spirit or body. The human being has consciousness of survival in God (baqa') and sees himself as part of eternity. In other words, the love felt by Rabia is all a process of moral and spiritual experience. Rabia represents all stages of this journey as nodes. She does not refer to any haals or levels. After some years, Sufi thinkers have classified haal and maqams, their sequences and means. However, in the poems of Rabia, they look like a point rather than a line. She writes:

I have loved Thee with two loves:

a selfish love and a love that is worthy of Thee.

As for the love which is selfish,

Therein I occupy myself with Thee, 
to the exclusion of all others.

But in the love which is worthy of Thee,

Thou dost raise the veil that I may see Thee.

Yet is the praise not mine in this or that,

But the praise is to Thee in both that and this (al-Adawiyya 2016: 97).

First, the poem depicts human love, that is, the love of a being who lives in the material world but has a divine spirit. Rabia notes that each side has its own love. One needs material goods, and the other seeks its primary roots in the divine world. She says that selfish love occupies itself entirely with God 'to the exclusion of all others'. This means that it loves within the material world. Second, Rabia goes beyond the matter, because 'Thou dost raise the veil that I may see Thee'. It gives the opportunity to see the Creator in all creatures. This is the process of cognition, passing from the external world to the inner world, the heart, haal of certainty.

After some years, this process will be formulated as 'Ilm al-Yaqin (The Knowledge of Certainty), 'Ayn al-Yaqin (The Eye of Certainty) and Haqq al-Yaqin (The Truth of Certainty). Mansur Hallaj (Hallaj 1913) replaces the word 'yaqin' with 'Haqaiqah' (Truth). Indeed, the end of the sufi way - shari'ah-tariqah-ma 'rifat-haqiqah - is Truth. However, in Rabia's representation there is only Truth - Love. Thus, the Sufi formula of the process of cognition acquires a new meaning: 'Ilm al-Asyq (The Knowledge of Love), 'Ayn al-Asyq (The Eye of Love) and Haq al-Asyq (The Truth of Love). It should be noted that in most cases love is represented as a feeling, which is why the introduction of Sufism as "a science of love" means restricting the essence of Sufism. However, Rabia's ideas claim that love is a process of cognition of divine knowledge.

Indeed, Rabia, who writes about the highest moments of love, never forgets that humankind is also a material being. Hereby, she notes that in these moments becoming as close as possible to God is attainable for everyone who seeks divine love and knowledge. She writes:

My peace, 0 my brothers and sisters, is my solitude,

And my Beloved is with me always,

For His love I can find no substitute,

And His love is the test for me among mortal beings,

Whenever His Beauty I may contemplate,

He is my mihrab, towards Him is my qiblah (Sufi Poems 2015).

Certainly, it is very difficult to seek divine love while the material body needs material goods. That is why Rabia says: "His love is the test for me among mortal beings" (Smith 1928: 38). There is a paradox here: if material needs surpass all other desires they can destroy divine love; but if divine love surpasses this it can be a lighthouse, mihrab/niche for other feelings and improve them. The Creator is not only a companion, but He is a Teacher, too. Love is the translator of His language. His truth is not for the mystic or non-real world, but for human society. In other words, although the love is divine, its truth is something for humankind. For Stein, the last stage is abandonment of the will. She writes: "Love finally frees the will from all things, since it obliges the will to love God above all" (Stein 2002: 46).

Indeed, God is love. The heart should be ready to receive from this eternity. It does this through purification, otherwise the love remains incomplete. As Meister Eckhart said:

"Although God is Almighty, He can only work in a heart when He finds readiness or makes it. ... If the heart is to be ready for the highest, it must be vacant of all other things.... If God is to write on my heart, everything else must come out of it till it is indeed sanctified. Only so can God work His highest will, and so the sanctified heart has no outward object at all" (Eckhart 2005: 14). 
For Stein, to be ready for God's love and works is to be in union with God. She writes: "The higher degree of the union of love to which God desires to lead them, the more intense and prolonged will the purification be" (Stein 2002: 39). There is an important point here: God and His love can only teach and lead to perfection, the highest levels of morality and knowledge, because the human being does not yet know this world. Stein (2002: 43) writes: "The way that leads to the high mountain of perfection can only be traveled by those who are not weighed down by any burden".

God knows man better than he does himself, and He (God) can be in touch with the divine core - the heart. When humankind purifies itself through faith and hope, it can achieve the divine core and divine love. In this world and at this moment, humankind is a different being with new knowledge, new devices and a new Truth. Indeed, love is at the intersection of the divine and human wills, or in other words at the point where the human will dissolve into the divine will. Sufi thinkers call this moment the haal of fana (extinction). The next haal is baqa' (survival in God).

Consequently, the third stage is the final and decisive moment of the whole process. First, it is the triumph of love. It can be called the goal of process, as this level is the union with God. The two previous stages are preparatory stages, where there is total ignorance. Faith and hope are a seeking for light in the darkness. Love is the same light. Faith and hope can also be called a transition. They are connected with the material world on the one hand, and on the other with the divine world. However, love is connected only with the spirit and the heart, and it is an opportunity to be in touch with God. Second, the third stage is the place where human love dissolves into divine love. Stein writes:

The supernatural union exits when God's will and the soul's are in conformity, so that nothing in the one is repugnant to the other. When the soul "rids herself completely of what is repugnant and unconfirmed to the divine will, she rests transformed in God through love (Stein 2002: 45).

Therefore, love is the moment of union with God and the acquisition of a new personality and morality. Although the material body remains in this world, the spirit rises beyond all mortal beings. In conclusion, the third stage is the acquisition of a new source of knowledge. When we considered faith and hope, we repeatedly noted that the mind of man seeks to find light in the darkness, and empties its memory, waiting for new knowledge. Love is a process involving vision of the light and the receiving of new knowledge. In other words, it is the end of rational thought and the beginning of the irrational way. It should be noted that before the third stage humankind is purified by phenomenological reduction - the act of bracketing of the real status and knowledge. As a result of this process or epoche the human being abandons his previous life and logical conclusions and receives the noematic core, the heart.

We have considered love from different angles: as a motive force, a goal, and a beginning point. Does this show some contradictions? No. Love envelops the person both externally and internally. Humankind exists in as a possession of God, who is everywhere. When he perceives the Creator in every being and every creature, he sees the divine light that helps him to recognize his heart. If we are using phenomenological terms, we can call love intentionality. However, the intentionality in Husserl's phenomenology is a feature of consciousness, and in Rabia's thoughts and Stein's phenomenology love is a feature of the spirit. In phenomenology the main idea is the pure consciousness, and for Rabia and Stein the main idea is the pure heart that can find Absolute Truth through love. The culminative moment is the noematic core, where humankind is in direct touch with God. Stein writes: "But the most region of the soul is the place where God lives "all alone", as long as the soul has not reached the perfect union of love" (Stein 2002: 147). She thought that, "God is in the inmost depth of the soul and nothing is in her is hidden from him" 
(Stein 2002: 140). Although love is the third stage, from the point of view of intention, it is everywhere. It is in the power of the heart to represent and reintroduce the object in a different light.

In conclusion, we would like to point out some important and shared features in the thoughts of Rabia and Stein. First, although they were true believers and based their work on holy books, their thoughts on divine love transcended official religion and were based on their philosophical views. Both of them wrote based on their own spiritual experiences. The beginning point is the heart/soul, and the end is union with God. Accordingly, their thought cannot be called preachings or religious texts. On the contrary, both of them can open horizons owing to the methods of their philosophies, Sufism and Phenomenology. Edith Stein's fame is not as wide as Rabia's; however, she is also a striking person in the history of philosophy.

Second, the spiritual way, which is reintroduced by Rabia and Stein, is a process of cognition. Thus, the processes of 'Ilm al-Asyq (The Knowledge of Love), 'Ayn al-Asyq (The Eye of Love) and Haqq al-Asyq (The Truth of Love) are the essence of the phenomenology of love. The goal is to seek divine light and divine love in the essence of humankind, and to recognize truth at the intersection of divine and human love.

\section{References}

al-Adawiyya, Rabi'a. 2016. Life \& Poems. Translated by Paul Smith. n.l.: CreateSpace Independent Publishing Platform.

Eckhart, Meister. 2005. Sermons. Translated by Claud Field. n.l.: Old Land Mark Publishing. Hallaj, Mansur. 1913. Kitab at-Tawasin. Edited by Louis Massignon. Paris: n.p.

Ladinsky, Daniel (ed.). 2002. Love Poems from God: Twelve Sacred Voices from the East and West. New York: Penguin Compass.

Sezer, Mesut (ed.). 2015. Sufi Poems: A mystic collection from some spiritual poets. https://books.google.az/books/about/Sufi_Poems.html?id=iy1oBgAAQBAJ\&redir_esc=y . Retrieved: 15th of May 2020.

Smith, Margaret. 1928. Rabi'a, The Mystics and Her Fellow-saints in Islam. Lahore: Kazi Publications.

Stein, Edith. 2002. The Science of the Cross. Translated by J. Koeppel. n.l.: ICS Publications. 